\title{
Pengaruh proses fermentasi kacang merah (phaseolus vulgaris 1.) menggunakan ragi tempe (rhizopus sp.) dan enzim papain terhadap kualitas sosis kacang merah
}

\author{
Effect of Fermentation Process Red beans (Phaseolus vulgaris L.) Using Yeast Tempeh \\ (Rhizopus Sp.) and Papain Enzymes on the Quality Red Beans Sausage
}

\author{
Siti Mutmainah", Ana Ummu Mas'ula ${ }^{1)}$, Septiani Budi Ariska ${ }^{1)}$, Lailatul \\ Masruroh $^{1)}$, Hapsari Titi Palupi ${ }^{2}$ \\ ${ }^{1}$ Mahasiswa S1 Program Studi Ilmu dan Teknologi Pangan, Fakultas Pertanian, Universitas \\ Yudharta Pasuruan \\ ${ }^{2}$ Dosen Program Studi Ilmu dan Teknologi Pangan, Fakultas Pertanian, Universitas Yudharta \\ Pasuruan \\ Jalan Pesantren Ngalah No 16 Pandean Sengonagung Purwosari Pasuruan 67162 \\ Email : mutmainnahmudzakkir36@gmail.com
}

Dikirim: 10/09/2019; ditinjau: 15/09/2019; disetujui: 30/09/2019

\begin{abstract}
Red beans (Phaseolus vulgaris L.) is a commodity beans are very popular, and are abundant in Indonesia. The purpose of this study to determine the effect of different fermentation methods on quality sausage red beans and determine the best fermentation method on the sausage red beans based on the analysis and organoleptic clams. The method used in this study is RAK one single factor consisting of four treatments. F1 (red bean fermentation using yeast tempeh (Rhizopus oligosporus)), F2 (fermented using enzymes papain), F3 (red bean fermentation using yeast tempeh (Rhizopus oligosporus) + enzyme papain) and F4 (without red bean fermentation process). The observations were analyzed using statistical ANOVA (Analysis of Variance) followed by Tukey test sensory testing is carried out by Friedman test. The best treatment method de Garmo effectiveness index. The results showed Effect of treatment fermentation methods which differ significantly affect chemical parameters include moisture content, ash content, protein content, fat content rude, crude fiber content and carbohydrate content and the nature organolepti color, aroma, flavor, and texture of the sausage beans. best fermentation method in the manufacture of sausages red beans based on a chemical that is F4 (without red bean fermentation process) with a value of $9.29 \%$ moisture content, ash content of $4.41 \%, 12.47 \%$ protein content, fat content rough $0.51 \%$, crude fiber content of $3.71 \%$, and the carbohydrate content of $73.3 \%$. While the treatment is the best value organoleptic F1 (red bean fermentation using yeast tempeh (Rhizopus oligosporus)) Color 8 (really like), the scent 7.48 (like), flavor 6.6 (a bit like), and the texture of 7.92 (very like).
\end{abstract}

Keywords: red beans, methods of fermentation, sausage

\begin{abstract}
ABSTRAK
Kacang merah (Phaseolus vulgaris L.) merupakan komoditas kacang-kacangan yang sangat dikenal masyarakat dan tersedia melimpah di Indonesia. Tujuan penelitian ini untuk mengetahui pengaruh metode fermentasi yang berbeda pada kualitas sosis kacang merah dan mengetahui metode fermentasi terbaik pada sosis kacang merah berdasarkan analisis kima dan organoleptik. Metode yang digunakan dalam penelitian ini adalah RAK satu factor tunggal terdiri dari empat perlakuan. F1 (fermentasi kacang merah menggunakan ragi tempe (Rhizopus oligosporus)), F2 (fermentasi menggunakan enzim papain ), F3 (fermentasi kacang merah menggunakan ragi tempe (Rhizopus oligosporus) + enzim papain), dan F4 ( tanpa proses fermentasi kacang merah). Hasil pengamatan dianalisis menggunakan statistic ANOVA (Analysis of Variance) dilanjutkan dengan Uji Tukey. Sedangkan uji sensoris dilakukan dengan Uji Friedman.
\end{abstract}


Perlakuan terbaik menggunakan metode indeks efektivitas de Garmo. Hasil penelitian menunjukkan Pengaruh perlakuan metode fermentasi yang berbeda berpengaruh nyata terhadap parameter kimia yang meliputi kadar air, kadar abu, kadar protein, kadar lemak kasar, kadar serat kasar dan kadar karbohidrat serta sifat organolepti warna, aroma, rasa, dan tekstur sosis kacang merah.Metode fermentasi terbaik pada pembuatan sosis kacang merah berdasarkan parameter kimia yaitu F4 (tanpa proses fermentasi kacang merah) dengan nilai kadar air 9,29\%, kadar abu 4,41\%, kadar protein 12,47\%, kadar lemak kasar 0,51\%, kadar serat kasar 3,71\%, dan kadar karbohidrat $73,3 \%$. Sedangkan nilai terbaik organoleptik yaitu perlakuan F1 (fermentasi kacang merah menggunakan ragi tempe (Rhizopus oligosporus)) warna 8 (sangat suka), aroma 7,48 (suka), rasa 6,6 (agak suka), dan tekstur 7,92 (sangat suka).

Kata Kunci : kacang merah, metode fermentasi, sosis

\section{PENDAHULUAN}

Kacang merah (Phaseolus vulgaris L.) merupakan komoditas kacang-kacangan yang sangat dikenal masyarakat dan tersedia melimpah di Indonesia. Hal tersebut sesuai dengan data Badan Pusat Statistik (2014). Di Indonesia terdapat berbagai jenis sumber daya yang dapat digunakan sebagai pengganti protein diantaranya adalah kacang merah dan tempe. Kacang merah dan tempe ini dapat dimanfaatkan dalam pembuatan daging analog (Yusniardi dkk., 2010). Kandungan protein dalam kacang merah, sudah lama diakui kontribusinya pada menu makanan sehari-hari. Bahkan kacang merah memasok kebutuhan protein hampir sama banyaknya dengan daging. Hal ini menunjukkan bahwa berdasarkan kandungan nutrisinya terutama protein, kacang merah berpotesi untuk bisa dijadikan sebagai (meat analog) (Astawan, 2009).

Sosis adalah produk daging yang diagaram dan dibumbui, berasal dari bahasa latin Salsus (garam) (Raharjo dan Warsito, 2002). Dalam pembuatan sosis daging yang berasal dari hewan adalah sumber protein hewani. Daging memiliki banyak kandungan asam amino essensial yang tidak dapat disintesis oleh tubuh manusia secara langsung tetapi diperoleh dari luar. Manfaat dari daging hewani itu sendiri sangat banyak di antaranya, sebagai sumber kalori terbesar bagi manusia (Widjanarko, 2010).

Permasalahan yang sering kali timbul dalam pembuatan sosis ialah pecahnya emulsi, tekstur yang meremah (tidak kompak), terlalu keras maupun terlalu lembek, dan daya ikat air yang rendah akibat proses perlakuan emulsifikasi yang tidak baik. Mutu sosis dapat ditingkatkan dengan menaikkan daya ikat air dan emulsi lemak menggunakan bahan pengikat dan pengisi yang tepat (Kramlich, 1971). Berdasarkan permasalahan dalam pembuatan sosis tersebut, pada penelitian ini akan diteliti pengaruh fermentasi menggunakan ragi tempe Ryzopus oligosporus yang merupakan jamur yang berperan dalam fermentasi pembuatan tempe yang mempunyai beberapa sifat penting antara lain meliputi: aktivitas enzimatiknya, kemampuan menghasilkan antibiotika, biosintesa vitamin vitamin B, kebutuhannya akan senyawa sumber karbon dan nitrogen, perkecambahan spora, dan penertisi miselia jamur tempe ke dalam jaringan biji kedelai (Nouth and Kiers, 2005). Selain itu akan disertakan peranan enzim papain yang terdapat pada getah pepaya yang merupakan jenis enzim proteolitik yaitu enzim yang mengkatalisa reaksi pemecahan rantai polipeptida pada protein dengan cara menghidrolisa ikatan peptidanya menjadi senyawa-senyawa yang lebih sederhana seperti dipeptida dan asam amino (Permata, 2016).

\section{METODE PELAKSANAAN}

\section{Waktu dan tempat penelitian}

Penelitian dilaksanakan pada bulan Desember 2016 sampai bulan Oktober 2017 di Laboratorium Universitas Yudharta Pasuruan

\section{Bahan}

Bahan baku utama pembuatan sosis kacang merah adalah kacang merah yang dibeli di Pasar Sukorejo, ragi tempe 
(Rhizopus oligosporus) yang dibeli dari pengerajin tempe di Kecamatan Sukorejo, enzim papain yang ditoreh dari jenis Pepaya Hawai, tepung tapioca merek Rose Brand, putih telur, tepung terigu merek Cakra, bawang merah, bawang putih , garam, merica, gula, STTP, es batu dan pewarna merah merek Red Bell. Bahan untuk Bahan kimia yang digunakan adalah $\mathrm{Na} 2 \mathrm{~S} 04$, $\mathrm{CuS04}, \mathrm{H} 2 \mathrm{~S} 04, \mathrm{NaOH} 45 \%, \mathrm{HCl} 0,1 \mathrm{M}$, $\mathrm{NaOH} 1 \mathrm{M}, \mathrm{HCl}$ 0,2 M, NaOH 0,3 M, etanol pro analis, etanol $80 \%$, n-heksan, etil asetat, akuades, larutan baku $\beta$-karoten, $\mathrm{Na} 2 \mathrm{CO} 32 \%$.

Alat

Alat yang digunakan dalam penelitian ini antara lain: timbangan analitik,timbangan, gelas ukur, baskom, kompor, sendok, saringan, pengaduk, nampan, ayakan 60 mesh, panci, dan mesin penggiling. Alat untuk analisis yaitu alat-alat gelas (pyrex Iwaki), blender (Phillip), mikropipet (Brand), alumunium voil, vorteks, ayakan, neraca analitik ER-180, oven (Mammert), desikator, sentrifugasi, tanur dan spektrofotometer UV-Vis 1800 Series (Shimadzu).

\section{Metode}

Rancangan penelitian yang

digunakan adalah Rancangan Acak

Kelompok satu faktor tunggal terdiri dari empat perlakuan. Perlakuan yang diberikan berupa :

\begin{tabular}{|c|c|c|c|}
\hline $\mathrm{F} 1=$ & $\begin{array}{l}\text { Fermentasi } \\
\text { menggunakan } \\
\text { (Rhizopus oliq }\end{array}$ & $\begin{array}{r}\text { kacang } \\
\text { ragi } \\
\text { gosporus) }\end{array}$ & $\begin{array}{l}\text { merah } \\
\text { tempe }\end{array}$ \\
\hline $2=$ & $\begin{array}{l}\text { Fermentasi } \\
\text { papain }\end{array}$ & menggunakan & enzim \\
\hline & $\begin{array}{l}\text { Fermentasi } \\
\text { menggunaka }\end{array}$ & kacang & \\
\hline
\end{tabular}

$\mathrm{F} 4=$ Tanpa proses fermentasi kacang merah.

Masing-masing dari perlakuan terdiri dari tiga kali ulangan sehingga diperoeh 12 kombinasi perlakuan. Perubah penelitian meliputi uji sensoris (rasa,warna,tekstur, aroma, tingkat kesukaan), dan uji kimia (kadar air, kadar abu, kadar protein, kadar lemak, dan kadar karbohidrat). Proses pembuatan sosis berbahan baku kacang merah terdapat pada gambar 1 .

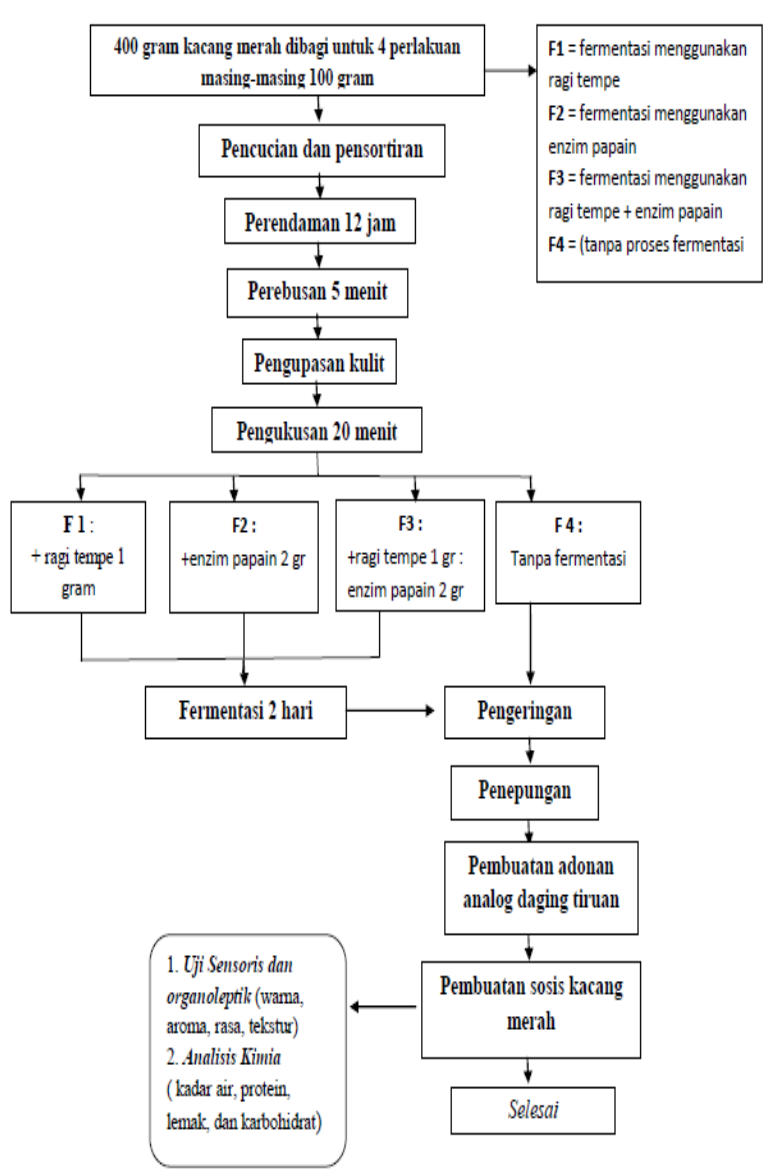

Gambar 1. Diagram alir proses pembuatan sosis berbahan baku kacang merah

\section{HASIL DAN PEMBAHASAN}

\section{Kadar air}

Berdasarkan hasil analisis kadar air sosis kacang merah (Phaseolus vulgaris L) diperoleh rata-rata 8,84\%-11,53\%. Analisis ANOVA (Analysis of Variance) 5\% menunjukkan bahwa kombinasi perlakuan metode fermentasi yang berbeda pada sosis kacang merah (Phaseolus vulgaris L) berpengaruh sangat nyata terhadap kadar air sosis. Rata-rata nilai kadar air dalam setiap perlakuan dapat dapat dilihat pada gambar 2 . 


\section{Rata-Rata Kadar Air (\%)}

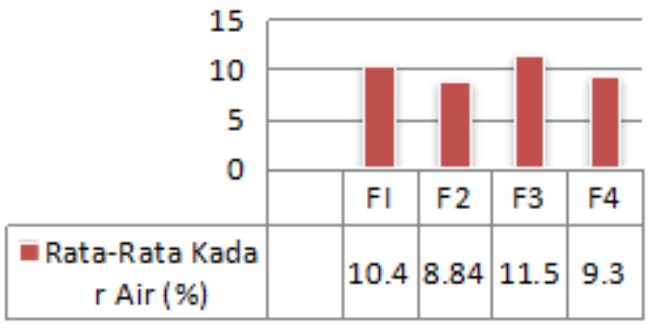

Gambar 2. Grafik rata-rata kadar air sosis kacang merah

Berdasarkan gambar grafik 2 diatas menunjukkan bahwa proses fermentasi dengan penambahan ragi tempe (Rhizopus oligosporus) dan enzim papain memberikan pengaruh terhadap hasil analisa kadar air sosis berbahan baku kacang merah. Hasil rata-rata tertinggi yaitu pada perlakuan F3 (Fermentasi kacang merah menggunakan ragi tempe + enzim papain) yaitu $11,533 \%$ hal ini dikarenakan proses fermentasi kacang merah menggunakan ragi tempe (Rhizopus oligosporus) dan enzim papain mempengaruhi meningkatnya kadar air disebabkan proses metabolisme mikroorganisme Rhizopus oligosporus dengan enzim papain saat proses fermentasi. Kehilangan bahan kering atau peningkatan kadar air pada sosis berbahan baku kacang merah saat fermentasi disebabkan adanya proses konversi bahan oleh Aspergillus niger untuk aktivitas pertumbuhannya dengan melakukan proses respirasi sehingga terjadi penguapan saat fermentasi. Bahan kering dikonversi oleh kapang menjadi energi, karbondioksida (CO2) dan air (H2O) (Mirwandhono dan Siregar 2004).

Sedangkan kadar air terendah yaitu pada perlakuan F2 (Fermentasi kacang merah menggunakan enzim papain) dengan rata-rata $8,84 \%$. Hal ini dikarenakan penambahan enzim mampu menurunkan nilai kadar air produk. Enzim proteolitik bersifat larut dalam air, sehingga terjadi sintesis air oleh enzim tersebut. Hidrolisis protein oleh enzim protease akan memutuskan ikatan peptida yang terdapat pada protein. Proses pemutusan ini membutuhkan air, semakin aktif daya proteolitiknya maka semakin banyak kebutuhan akan air, sehingga dapat menurunkan nilai aktivitas air pada bahan (Usmiati, 2011).

\section{Kadar abu}

Berdasarkan hasil analisis kadar abu sosis berbahan baku kacang merah diperoleh rata-rata 3,42\% - 4,41\%. Analisis ANOVA (Analysis of Variance) menunjukkan bahwa kombinasi perlakuan metode fermentasi yang berbeda berpengaruh sangat nyata terhadap nilai kadar abu sosis kacang merah. Perlakuan dengan nilai kadar abu tertinggi yaitu pada perlakuan F4 (tanpa proses fermentasi kacang merah) dengan rata-rata kadar abu 4,41\%. Rata-rata kadar abu sosis berbahan baku kacang merah disajikan pada gambar 3 .



Gambar 3. Grafik rata-rata kadar abu sosis kacang merah

Berdasarkan gambar grafik 3 diatas menunjukkan bahwa proses fermentasi dengan metode yang berbeda memberikan pengaruh terhadap hasil analisa kadar abu sosis berbahan baku kacang merah. Hasil rata-rata tertinggi yaitu pada perlakuan $\mathrm{F} 4$ (tanpa proses fermentasi kacang merah) dengan rata-rata $4,41 \%, F 1$ (fermentasi kacang merah menggunakan ragi tempe (Rhizopus oligosporus)+ enzim papain) 4,27\%, F3 (fermentasi kacang merah menggunakan ragi tempe (Rhizopus oligosporus)) $3,82 \%$ dan nilai kadar abu terendah yaitu pada perlakuan F2 (fermentasi kacang merah menggunakan enzim papain) dengan rata-rata 3,42\%.

Kadar abu yang diukur bermanfaat untuk mengetahui besarnya kandungan 
mineral yang terdapat dalam sampel bahan. Fungsi dari kadar abu tersebut yaitu mengetahui bahwa semakin tinggi kadar abu suatu bahan pangan, maka semakin buruk kualitas dari bahan pangan tersebut (Sudarmadji, 2003).

\section{Kadar protein}

Berdasarkan hasil analisis kadar protein sosis berbahan baku kacang merah diperoleh rata-rata $9,38 \%-12,47 \%$. Analisis ANOVA (Analysis of Variance) menunjukkan bahwa kombinasi perlakuan metode fermentasi yang berbeda berpengaruh sangat nyata terhadap nilai kadar protein sosis kacang merah. Perlakuan dengan nilai kadar protein tertinggi yaitu pada perlakuan F4 (tanpa proses fermentasi kacang merah) $12,47 \%$. Rata-rata kadar protein pada setiap perlakuan dapat dilihat pada gambar 4 .

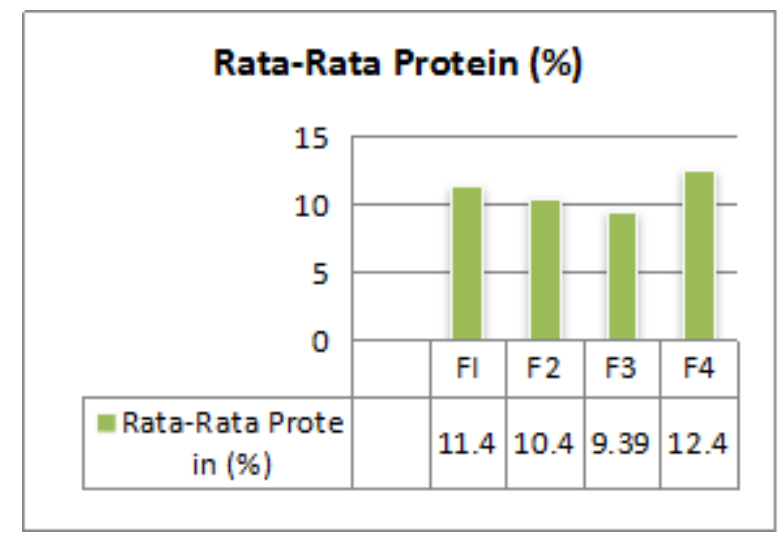

Gambar 4. Grafik rata-rata kadar protein sosis kacang merah

Pada gambar grafik 4 menunjukkan bahwa nilai kadar protein tertinggi pada perlakuan F4 (tanpa proses fermentasi kacang merah) dengan rata-rata $12,47 \%$. Hal ini dikarenakan pada perlakuan $\mathrm{F} 4$ tidak terjadi proses fermentasi sehingga tidak terjadi pemecahan protein menjadi asam amino atau pemecahan senyawa kompleks menjadi sederhana. Sedangkan nilai kadar protein terendah yaitu pada perlakuan F3 (fermentasi kacang merah menggunakan ragi tempe (Rhizopus oligosporus)+ enzim papain) dengn rata-rata 9,38\%. Hal ini terjadi karena Selama proses fermentasi terjadi penurunan kadar protein yang disebabkan terjadinya pemecahan protein menjadi asam amino dan peptida-peptida rantai pendek, penurunan kadar protein disebabkan karena jamur Rhizopus oligosporus bersifat proteolitik dan ini penting dalam pemecahan protein (Hesseltine dan Wang ,1983).

Jamur Rhizopus oligosporus akan mendegradasi protein selama fermentasi menjadi dipeptida dan seterusnya menjadi senyawa NH3 atau N2 yang hilang melalui penguapan (Bolsen, 2001). Selain itu, penambahan enzim papain juga mempengaruhi menurunnya kadar protein karena enzim papain disebut juga enzim proteolitik atau disebut juga proteinase atau protease, merupakan kelompok enzim yang mampu memecah rantai panjang molekul protein menjadi molekul-molekul yang lebih kecil disebut peptida (peptides) dan bahkan sampai menjadi komponen-komponen terkecil penyusun protein yang disebut asam amino (Amino Acid) (Chaidir, 2012).

Fermentasi dapat juga berlangsung dengan menggunakan ekstrak enzim yang berfungsi sebagai katalisator reaksi. (Leni herliani, 2008). Sehingga dengan penambahan enzim papain turut mempercepat proses fermentasi dan menurunkan kadar protein akan tetapi meningkatkan nilai cerna produk sosis berbahan baku kacang merah. Secara kuantitatif nilai gizi sosis kacang merah terfermentasi sedikit lebih rendah dari pada tanpa fermentasi, akan tetapi secara kualitatif nilai gizinya lebih tenggi karena mempunyai nilai cerna yang lebih baik.

\section{Kadar lemak kasar}

Berdasarkan hasil analisis kadar lemak sosis berbahan baku kacang merah diperoleh rata-rata $0,28 \%-0,51 \%$. Analisis ANOVA (Analysis of Variance) menunjukkan bahwa kombinasi perlakuan metode fermentasi yang berbeda berpengaruh sangat nyata terhadap nilai kadar lemak sosis berbahan baku kacang merah. Perlakuan terbaik dengan nilai kadar lemak tertinggi yaitu pada perlakuan F4 (Tanpa proses fermentasi kacang merah) $0,51 \%$. Rata-rata kadar lemak pada setiap perlakuan terdapat pada gambar 5 . 


\section{Rata-Rata Kadar Lemak Kasar (\%)}

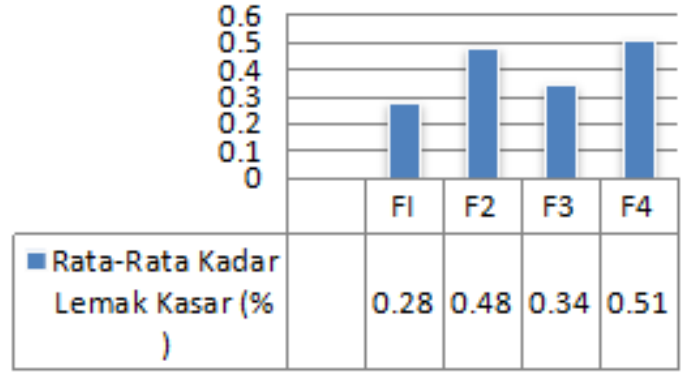

Gambar 5. Grafik rata-rata kadar lemak kasar sosis kacang merah

Berdasarkan gambar 5 rata-rata kadar lemak kasar sosis kacang merah secara berturut-turut dari yang tertinggi yaitu F4 (Tanpa proses fermentasi kacang merah) $0,51 \%$, F2 (Fermentasi kacang merah menggunakan enzim papain) $0,47 \%, \mathrm{~F} 3$ (Fermentasi kacang merah menggunakan ragi tempe (Rhizopus oligosporus)+ enzim papain) 0,34\%, dan F1 (Fermentasi kacang merah menggunakan ragi tempe (Rhizopus oligosporus)) $0,28 \%$. Hal ini didukung oleh Rarumangkay (2002), yang menyatakan bahwa selama proses fermentasi, terjadi reaksi oksidasireduksi yang menghasilkan energi sebagai donor dan akseptor elektron, serta terjadi perubahan kimiawi dan selanjutnya diubah oleh reaksi reduksi dengan katalis enzim, serta kandungan kadar lemak yang tinggi dapat menghambat proses fermentasi.

\section{Kadar serat kasar}

Berdasarkan hasil analisis kadar serat kasar sosis berbahan baku kacang merah diperoleh rata-rata $3,51 \%-11,15 \%$. Analisis ANOVA (Analysis of Variance) menunjukkan bahwa kombinasi perlakuan metode fermentasi yang berbeda berpengaruh sangat nyata terhadap nilai kadar serat kasar sosis berbahan baku kacang merah. Perlakuan terbaik dengan nilai kadar lemak tertinggi yaitu pada perlakuan $\mathrm{F} 4$ (Tanpa proses fermentasi kacang merah) $11,15 \%$. Rata-rata kadar serat kasar pada setiap perlakuan dapat dilihat pada gambar 6 .

\section{Rata-Rata Kadar Serat Kasar (\%)}



Gambar 6. Grafik rata-rata kadar serat kasar sosis kacang merah

Berdasarkan gambar 6. rata-rata kadar serat kasar sosis berbahan baku kacang merah berturut-turut dari yang tertinggi yaitu F4 (tanpa proses fermentasi kacang merah) $3,71 \%$, F2 (fermentasi kacang merah menggunakan ragi tempe (Rhizopus oligosporus)) 2,07\%, F3 (fermentasi kacang merah menggunakan ragi tempe (Rhizopus oligosporus)+ enzim papain) $1,37 \%$, dan F2 (fermentasi kacang merah menggunakan enzim papain) $1,17 \%$. hal ini disebabkan perlakuan F4 tidak mengalami proses fermentasi sehingga tidak terjadi penurunan kandungan serat kasar, sedangkan perlakuan $\mathrm{F} 1$,F2, dan F3 mengalami proses fermentasi sehingga mengalami penurunan kandungan serat kasar, sesuai dengan pernyataan Yang et al., (2005) menyatakan bahwa sebagian besar jamur dapat menghasilkan enzim ligninase dan enzim selulase, yaitu enzim yang dapat mengurai ikatan lignin dan selulosa. Hal ini didukung oleh Volk (2004) menyatakan bahwa jamur Trichoderma viride sebagai penghasil enzim selulose lengkap yang dibutuhkan untuk menghidrolisis selulosa dan kristal yang menyebabkan penurunan kandungan serat kasar.

\section{Kadar karbohidrat}

Berdasarkan hasil analisis kadar karbohidrat sosis berbahan baku kacang merah diperoleh rata-rata 73,30\% - 76,82\%. Analisis ANOVA (Analysis of Variance) menunjukkan bahwa kombinasi perlakuan metode fermentasi yang berbeda berpengaruh sangat nyata terhadap nilai 
kadar karbohidrat sosis berbahan baku kacang merah. Perlakuan terbaik dengan nilai kadar karbohidrat tertinggi yaitu pada perlakuan F2 (Fermentasi kacang merah menggunakan enzim papain) 76,82\%. Ratarata kadar karbohidrat pada setiap perlakuan dapat dilihat pada gambar 7 .

\section{Rata-Rata Kadar Karbohidrat (\%)}



Gambar 7. Grafik rata-rata kadar karbohidrat sosis kacang merah

Nilai kadar karbohidrat pada sosis berbahan baku kacang merah merupakan jumlah perhitungan biasa yang dilakukan dengan menghitung secara keseluruhan antara kadar protein, kadar lemak, kadar air dan kadar abu. Hasil analisis karbohidrat tertinggi yaitu pada perlakuan F2 (fermentasi kacang merah menggunakan enzim papain ) dengan rata-rata kadar karbohidrat $76,82 \%$, dan terendah pada perlakuan F4 (tanpa proses fermentasi kacang merah) dengan rata-rata kadar karbohidrat $73,30 \%$ Hal ini sesuai pernyataan ( Winarno, 2004) bahwa perhitungan kadar karbohidrat suatu bahan pangan dapat dihitung secara perbedaan antara jumlah kandungan air, protein, lemak dan abu dengan rumus karbohidrat yaitu 100 - ( protein + lemak + abu + air ).

\section{Warna}

Uji hedonik terhadap warna sosis berbahan baku kacang merah diperoleh ratarata nilai 5,2 (netral ) - 8 (sangat suka). Hasil uji hedonik terhadap warna dari masingmasing perlakuan tersebut dapat dilihat pada Gambar 8 .

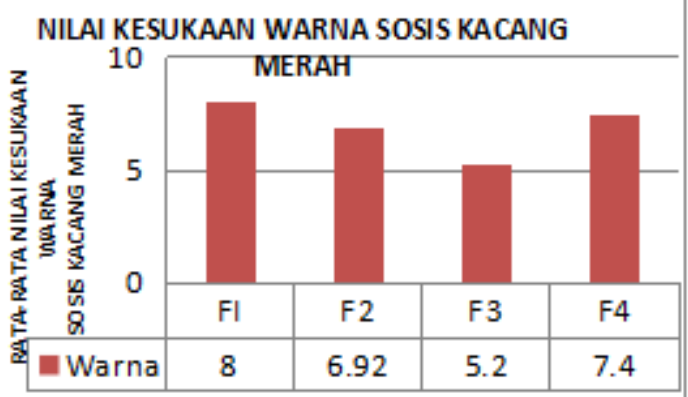

Gambar 8. Diagram rata-rata kesukaan warna sosis kacang merah

Dari hasil uji hedonik, dilakukan uji friedman yang merupakan metode non parametrik yang digunakan untuk rancanagan acak kelompok lengkap. uji friedman bertujuan untuk melihat ada atau tidaknya perbedaan pengaruh antar perlakuan. Berdasarkan uji friedman $\mathrm{P}<0,05$ $\mathrm{X} 2$ Tabel $(0,05: 3)=7,81<\mathrm{X} 2$ Hitung $=$ 24,75 yang berarti uji warna pada setiap perlakuan sosis kacang merah berpengaruh secara signifikan.

Berdasarkan data hasil uji hedonik diperoleh rata-rata uji orgonoleptik berdasarkan warna sosis berbahan baku kacang merah berturut-turut mulai dari tertinggi yaitu F1 (fermentasi kacang merah menggunakan ragi tempe (Rhizopus oligosporus)) rata-rata nilai 8,0 ( sangat suka), F4 (tanpa proses fermentasi kacang merah) rata-rata nilai 7,4 (suka), F2 (fermentasi menggunakan enzim papain) rata-rata nilai 6,92 (suka) dan terendah $\mathrm{F} 3$ (fermentasi kacang merah menggunakan ragi tempe (Rhizopus oligosporus) + enzim papain) rata-rata nilai 5,2 (netral).

Perlakuan F1 (fermentasi kacang merah menggunakan ragi tempe (Rhizopus oligosporus)) merupakan perlakuan terbaik dengan nilai tertinggi yaitu 8 (sangat suka) karena dengan fermentasi menggunakan ragi tempe (Rhizopus oligosporus) warna kacang merah lebih bisa menyerupai daging. Sedangkan nilai terendah yaitu pada perlakuan F3 (Fermentasi kacang merah menggunakan ragi tempe (Rhizopus oligosporus) + enzim papain ) dengan ratarata nilai 5,2 (netral) hal ini dikarenakan pada perlakuan ini fermentasi terjadi lebih 
cepat karena kombinasi antara ragi tempe Rhizopus oligosporus dan enzim papain sebagai katalisator sehingga mempercepat terjadinya reaksi maillard dan menghasilkan warna yang lebih gelap akibat hasil dari metabolisme mikroba. Sesuai dengan Astuti (2016) reaksi maillard merupakan rekasi yang terjadi antara gugus amino dari suatu amino bebas, residu rantai peptide atau protein dengan gugus karbonil dari suatu karbohidrat apabila keduanya dipanaskan atau disimpan pada waktu yang lama. Dari data tersebut dapat disimpulkan rata-rata dari semua perlakuan yaitu 6,88 (suka). Dengan demikian dari 25 panelis menyukai warna dari setiap perlakuan sosis berbahan baku kacang merah.

\section{Aroma}

Aroma merupakan salah satu faktor yang penting dalam menentukan mutu suatu bahan pangan. Hasil uji hedonik terhadap aroma dari masing-masing perlakuan dapat dilihat pada Gambar 9.

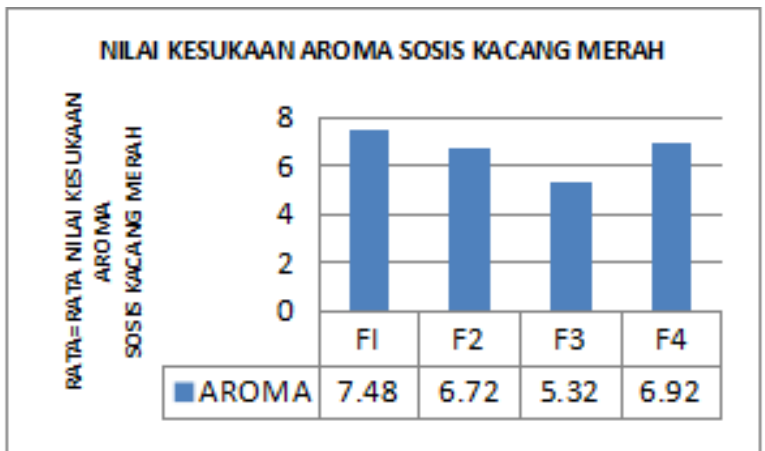

Gambar 9. Diagram rata-rata kesukaan aroma sosis kacang merah

Dari hasil uji hedonik, dilakukan uji friedman yang merupakan metode non parametrik yang digunakan untuk rancanagan acak kelompok lengkap. uji friedman bertujuan untuk melihat ada atau tidaknya perbedaan pengaruh antar perlakuan. Berdasarkan uji friedman $(\mathrm{P}>0,05) \quad \mathrm{X} 2$ Tabel $(0,05: 3)=7,81>\mathrm{X} 2$ Hitung $=12,108$ yang berarti uji aroma pada setiap perlakuan sosis kacang merah berpengaruh secara signifikan.

Berdasarkan data hasil uji hedonik diperoleh rata-rata uji orgonoleptik berdasarkan aroma sosis berbahan baku kacang merah berturut-turut mulai dari tertinggi yaitu F1 (fermentasi kacang merah menggunakan ragi tempe (Rhizopus oligosporus)) rata-rata nilai 7,48 (suka), F4 (tanpa proses fermentasi kacang merah) ratarata nilai 6,92 (suka), F2 (fermentasi menggunakan enzim papain) rata-rata nilai 6,72 (suka), dan terendah F3 (fermentasi kacang merah menggunakan ragi tempe (Rhizopus oligosporus) + enzim papain) ratarata nilai 5,32 (netral).

Berdasarkan hasil uji hedonik terhadap aroma diatas dapat dilihat bahwa tingkat kesukaan panelis terhadap aroma sosis berbahan baku kacang merah berada pada range antara netral sampai suka yaitu $5,32-7,48$. Nilai tertinggi tingkat kesukaan panelis terhadap aroma sosis berbahan baku kacang merah yaitu F1 (fermentasi kacang merah menggunakan ragi tempe (Rhizopus oligosporus)) rata-rata nilai 7,48 (suka), hal ini dikarenakan pada perlakuan $\mathrm{F} 1$, sosis berbahan baku kacang merah mengalami proses fermentasi menggunakan ragi tempe (Rhizopus oligosporus) saja sehingga fermentasi berjalan stabil dan aroma yang timbul adalah aroma khas fermentasi kapang Rhizopus oligosporus.

Sedangkan nilai terendah yaitu pada perlakuan F3 (fermentasi kacang merah menggunakan ragi tempe (Rhizopus oligosporus) + enzim papain) rata-rata nilai 5,32 (netral), hal ini disebabkan pada perlakuan F3 terjadi fermentasi antara ragi tempe (Rhizopus oligosporus) dan enzim papain sehingga aroma yang dihasilkan terlalu asam karena fermentasi berjalan dengan cepat disebabkan adanya enzim papain yang mampu memecah protein menjadi asam-asam amino, sesuai dengan pernyataan Chaidir (2012) bahwa enzim papain disebut juga enzim proteolitik atau disebut juga proteinase atau protease, merupakan kelompok enzim yang mampu memecah rantai panjang molekul protein menjadi molekul-molekul yang lebih kecil disebut peptida (peptides) dan bahkan sampai menjadi komponen-komponen terkecil penyusun protein yang disebut asam amino (Amino Acid). 
Rasa

Uji hedonik terhadap rasa sosis berbahan baku kacang merah diperoleh ratarata nilai 5,2 (netral )- 8,32 (sangat suka). Hasil uji hedonik terhadap rasa dari masingmasing perlakuan tersebut dapat dilihat pada Gambar 10.



Gambar 10. Diagram rata-rata kesukaan rasa sosis kacang merah

Dari hasil uji hedonik, dilakukan uji friedman yang merupakan metode non parametrik yang digunakan untuk rancanagan acak kelompok lengkap. uji friedman bertujuan untuk melihat ada atau tidaknya perbedaan pengaruh antar perlakuan. Berdasarkan uji friedman $(\mathrm{P}<0,05) \quad \mathrm{X} 2$ Tabel $(0,05: 3)=7,81>\mathrm{X} 2$ Hitung $=36,66$ yang berarti uji rasa pada setiap perlakuan sosis berbahan baku kacang merah berpengaruh secara signifikan.

Berdasarkan data hasil uji hedonik diperoleh rata-rata uji orgonoleptik berdasarkan aroma sosis berbahan baku kacang merah berturut-turut mulai dari tertinggi yaitu F4 (tanpa proses fermentasi kacang merah) rata-rata 8,32 (sangat suka), F1 (fermentasi kacang merah menggunakan ragi tempe (Rhizopus oligosporus)) 6,6 (suka), F2 (fermentasi menggunakan enzim papain) 5,2 (suka), dan terendah F3 (fermentasi kacang merah menggunakan ragi tempe (Rhizopus oligosporus) + enzim papain) 4,08 (agak tidak suka).

Perlakuan F4 (tanpa proses fermentasi kacang merah) dengan rata-rata nilai 8,32 (sangat suka) merupakan nilai tertinggi dikarenakan pada perlakuan F4 sosis berbahan baku kacang merah tidak mengalami proses fermentasi, sehingga tidak terjadi perubahan rasa pada kacang merah. Sedangakan perlakuan dengan nilai terendah yaitu F3 (fermentasi kacang merah menggunakan ragi tempe (Rhizopus oligosporus) + enzim papain) dengan ratarata nilai 4,08 (agak tidak suka). Hal ini dikarenakan pada karena pada perlakuan ini mempunyai rasa yang sedikit asam yang disebabkan oleh semakin meningkatnya jumlah asam-asam amino dan asam organik pada tahap fermentasi. Hal ini sesuai dengan pernyataan dari Musdholifah dan Zubaidah (2016) yang menyatakan bahwa semakin lama waktu fermentasi maka kadar gula akan menurun dan total asam meningkat yang menimbulkan rasa asam.

\section{Tekstur}

Uji hedonik terhadap tekstur sosis berbahan baku kacang merah diperoleh ratarata nilai 4,56 (agak tidak suka )- 7,92 (sangat suka). Hasil uji hedonik terhadap rasa dari masing-masing perlakuan tersebut dapat dilihat pada Gambar 11.

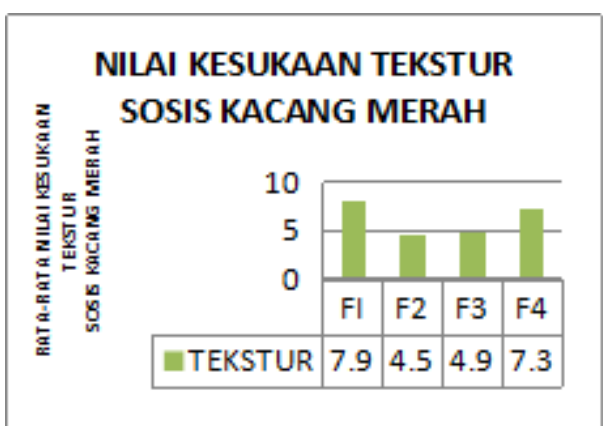

Gambar 11. Diagram rata-rata kesukaan tekstur sosis kacang merah

Dari hasil uji hedonik, dilakukan uji friedman yang merupakan metode non parametrik yang digunakan untuk rancanagan acak kelompok lengkap. uji friedman bertujuan untuk melihat ada atau tidaknya perbedaan pengaruh antar perlakuan. Berdasarkan uji friedman $(\mathrm{P}<0,05) \mathrm{X} 2$ Tabel $(0,05: 3)=7,81>\mathrm{X} 2$ Hitung $=23,37$ yang berarti uji hedonik tekstur pada setiap perlakuan sosis berbahan baku kacang merah berpengaruh secara signifikan. 
Berdasarkan data hasil uji hedonik diperoleh rata-rata uji orgonoleptik berdasarkan tekstur sosis berbahan baku kacang merah berturut-turut mulai dari tertinggi yaitu F1 (Fermentasi kacang merah menggunakan ragi tempe (Rhizopus oligosporus)) dengan rata-rata nilai 7,92 (sangat suka), F4 (tanpa proses fermentasi kacang merah) dengan rata-rata nilai 7,32 (suka), F3 (Fermentasi kacang merah menggunakan ragi tempe (Rhizopus oligosporus) + enzim papain) dengan ratarata nilai 4,96 (netral), dan nilai terendah yaitu pada perlakuan F2 (fermentasi menggunakan enzim papain) dengan ratarata nilai 4,56 (netral).

Perlakuan F1 (Fermentasi kacang merah menggunakan ragi tempe (Rhizopus oligosporus)) dengan rata-rata nilai 7,92 (sangat suka) merupakan nilai tertinggi dikarenakan pada perlakuan F1 sosis berbahan baku kacang merah mengalami proses fermentasi menggunakan ragi tempe (Rhizopus oligosporus) saja, sehingga terjadi pemecahan atau hidrolisis komponen kacang merah secara stabil dan menimbulkan tekstur sosis kacang merah yang disukai. Sedangkan nilai terendah yaitu pada perlakuan F2 (fermentasi menggunakan enzim papain) dengan rata-rata nilai 4,56 (netral). Hal ini disebabkan pada perlakuan F2 (fermentasi menggunakan enzim papain) mempunyai kandungan kadar air terendah. Hal ini sesuai dengan pernyataan Moniharapon (2013) kandungan air sangat berpengaruh terhadap tekstur (konsistensi bahan pangan). Pembebasan sejumlah air pada suatu produk pangan dapat mengakibatkan perubahan tekstur produk tersebut.

\section{Perlakuan terbaik}

Penilaian produk atau perlakuan terbaik sosis berbahan baku kacang merah terdapat pada gambar 12 .



Gambar 12. Nilai produk kimia dan organoleptik terbaik

Hasil perhitungan menunjukkan perlakuan terbaik yaitu perlakuan F4 (tanpa proses fermentasi kacang merah) dengan nilai parameter kimia yaitu kadar air 9,29\%, kadar abu 4,41\%, kadar protein 12,47\%, kadar lemak kasar 0,51\%, kadar serat kasar $3,71 \%$, dan kadar karbohidrat 73,3\%. Sedangkan nilai parameter organoleptik yaitu warna 7,4 (suka), aroma 6,92 (suka), rasa 8,32 (sangat suka), dan tekstur 7,32 (suka).

\section{KESIMPULAN}

\section{Kesimpulan}

1. Pengaruh perlakuan metode fermentasi yang berbeda berpengaruh nyata terhadap parameter kimia yang meliputi kadar air, kadar abu, kadar protein, kadar lemak kasar, kadar serat kasar dan kadar karbohidrat sosis kacang merah serta sifat organoleptik warna, aroma, rasa, dan tekstur sosis berbahan baku kacang merah.

2. Metode fermentasi terbaik pada pembuatan sosis kacang merah berdasarkan parameter kimia yaitu $\mathrm{F} 4$ (tanpa proses fermentasi kacang merah) dengan nilai kadar air 9,29\%, kadar abu $4,41 \%$, kadar protein $12,47 \%$, kadar lemak kasar $0,51 \%$, kadar serat kasar $3,71 \%$, dan kadar karbohidrat 73,3\%. Sedangkan nilai terbaik organoleptik yaitu perlakuan F1 (fermentasi kacang merah menggunakan ragi tempe (Rhizopus oligosporus)) warna 8 (sangat suka), aroma 7,48 (suka), rasa 6,6 (agak suka), dan tekstur 7,92 (sangat suka). 


\section{Saran}

1. Penelitian selanjutnya diharapkan dapat meneliti kandungan asam amino dari sosis fermentasi kacang merah untuk membandingkan nilai cernanya.

2. Penelitian selanjutnya diharapkan dapat menelti lama waktu fermentasi yang terbaik dalam pembuatan sosis fermentasi kacang merah.

3. Diharapkan penelitian selanjutnya juga dapat meneliti perbandingan karakteristik fisikokimia dan organoleptik sosis kacang merah dengan sosis yang beredar di pasaran.

\section{UCAPAN TERIMAKASIH}

Puji syukur kehadirat Allah SWT. atas segala limpahan rahmat dan karunianya. Dalam kesempatan kali ini penulis ingin mengucapkan banyak terimakasih kepada Kementrian Riset dan Teknologi Pendidikan Tinggi (RISTEK DIKTI) yang telah mendanai penelitian ini melalui hibah program kreatifitas mahasiswa (PKM), serta terimakasih kepada seluruh dosen program studi Ilmu dan Teknologi Pangan Universitas Yudharta Pasuruan yang telah memberikan banyak ilmu dan wawasan kepada penulis terkhusus kepada pembimbing yang telah membimbing dalam penyelesaian penelitian ini.

\section{DAFTAR PUSTAKA}

Astawan, M. (2009). Sehat dengan hidangan kacang dan biji-bijian (pp. 4-130). Jakarta : Penebar Swadaya.

Astuti, W., Hirajima, T., Sasaki, K., \& Okibe, N. (2016). Comparison of effectiveness of citric acid and other acids in leaching of low-grade Indonesian saprolitic ores. Minerals Engineering, 8(5), 1-16.

Kramlich, W. E. (1971). The science of meat and meat products (pp.484) (Ed. Price). JF : $\quad$ Schweigert.

Mirwandhono, E. \& Siregar J., (2004). Pemanfaatan hidrolisat tepung kepala udang dan limbah kelapa sawit yang difermentasi dengan
Aspergillus niger, Rizhopus

oligosporus dan Tricoderma virdiae dalam ransum ayam pedaging. Fakultas Pertanian Universitas

Sumatra. Retrieved from https://library.usu.ac.id/download/fp/te rnak-edhy.pdf

Muchtadi, T. R., \& Ayustaningwarno, F. (2010). Teknologi proses pengolahan pangan. Bandung : Alfabeta CV.

Nout, M. J. R., and Kiers, J.L. (2005). Tempe fermentation, innovation and functionality: update into the third millenium. Journal of Applied Microbiolog, 78,789-805

Permata, D. A., Ikhwan, H., \& Aisman, A. (2016). Aktivitas proteolitik papain kasar getah buah pepaya dengan berbagai metode pengeringan. Jurnal Teknologi Pertanian Andalas, 20(2), 58-64.

Raharjo, A. H. D., Wasito, \& Samsu. (2002). Buku ajar teknologi hasil ternak. Purwokerto: Universitas Jendral Soedirman.

Rarumangkay, J. (2015). Pengaruh fermentasi isi rumen sapi dengan trichoderma viride terhadap energi metabolis pada ayam broiler. zootec, 35(2), 312-318.

Sudarmadji, S., \& Bambang, H. (2003). Prosedur analisa bahan makanan dan pertanian. Yogyakarta: Liberty.

Usmiati, S., \& Juniawati, J. (2011). Karakteristik dadih probiotik menggunakan kombinasi lactobacillus casei, lactobacillus plantarum, dan bifidobacterium longum selama penyimpanan. Jurnal Gizi dan Pangan, 6(1), 1-12.

Wang, H. L. (1984). Tofu and tempeh as potential protein sources in the western diet. Journal of the American Oil Chemists' Society, 61(3), 528-534.

Widjanarko, S.B., Zubaidah E., \& Kusuma, A.M. (2010). Studi kualitas fisikkimiawi dan organoleptiksosis ikan lele dumbo (Clarias Gariepinus) akibat pengaruh perebusan, 
pengukusan dan kombinasinya dengan pengasapan. Jurnal Teknologi Pertanian, 4(3), 193-202.

Winarno, F. G., \& Silowati, S. Z. (2004). Keamanan pangan. Bogor : M-Brio Prees.

Yang, L., Parkin, D. M., Li, L. D., Chen, Y. D., \& Bray, F. (2004). Estimation and projection of the national profile of cancer mortality in China: 1991-2005. British journal of cancer, 90(11), 2157.

Yusniardi, E., Kanetro, B., \& Slamet, A. (2012). Pengaruh jumlah lemak terhadap sifat fisik dan kesukaan meat analog protein kecambah kacang tunggak (Vigna Uguicuata). Agritech. 30 (3), 148-151. 